\title{
Recording of Academic Transcript Data to Prevent the Forgery based on Blockchain Technology
}

\author{
Meyliana $^{1}$, Cadelina Cassandra ${ }^{*}, 1$, Yakob Utama Chandra ${ }^{1}$, Surjandy ${ }^{1}$, Erick Fernando ${ }^{1}$, Henry Antonius Eka Widjaja ${ }^{1}$, Harjanto \\ Prabowo ${ }^{2}$
}

${ }^{1}$ Information Systems Department, School of Information Systems, Bina Nusantara University, Jakarta, 11480, Indonesia

${ }^{2}$ Computer Science Department, Bina Nusantara University, Jakarta, 11480, Indonesia

\begin{tabular}{l} 
A R T I C L E I N F O \\
\hline Article history: \\
Received: 20 November, 2020 \\
Accepted: 05 February, 2021 \\
Online: 28 February, 2021 \\
\hline Keywords: \\
Blockchain \\
Multichain \\
Academic Transcript \\
Simulation \\
Forgery
\end{tabular}

\begin{abstract}
A B S T R A C T
Diploma certificate and transcript forgery is a serious issue in education. The government is still finding the best way to prevent and minimize this issue in the future. The diploma certificate and transcript are very easy to duplicate, not only from third parties. Even the university can easily produce a fake diploma certification and transcript for their benefit. Blockchain technology is a new technology and now can be used to prevent the fake graduation documents. This research shows the simulation of blockchain technology used (Multichain) for data recording of academic transcript as one of the graduation documents. FGD has been carried out by inviting several reputable universities to validate the prototype. As a result, the FGD participants validated the prototype and agreed if it possible to be implemented in university, especially for recording the academic transcript data. Recording the academic transcript on blockchain technology can contribute to prevent forgery.
\end{abstract}

\section{Introduction}

Diploma Certification forgery is not a new issue in Indonesia. Recently, in 2020 as reported from serambinews.com, it involved a Rector Candidate from one of Higher Education in Indonesia. A diploma certificate is still important in Indonesia for several positions. It is easy for university to produce the certification without any data validation [1]. This is not a new problem in Indonesia. Since 2015, there are many cases of diploma certification forgery. Many people got in this case and public figure and people in government too [2]. The publisher of this fake graduate information can be from a third party or even a legal university.

Looking at this problem, producing a certification for people that not even come and study to the university is very easy. The information is easily manipulated, and the user only needs to enter and create the data without any validation. So, data integrity is very important, every process that happens during university study needs to be locked, approved, and validated by stakeholder inside the university. Any data is not approved cannot be processed and every data in the application is immutable and unchangeable.

\footnotetext{
* Corresponding Author: Cadelina Cassandra, School of Information Systems, ccassandra@binus.edu

If this integrity is maintained in University, the graduation document will be hard to be duplicated or be falsified. Talking about this data integrity, blockchain is a technology that sure make this happen, mainly because of the features and capabilities of blockchain such as the security, reliability, integrity, and the concept of decentralization. Founded in 2008 by a group or person called Satoshi Nakamoto, blockchain is very popular and used in many areas, not only cryptocurrency [3]. Several studies show blockchain technology can be used as technology that can prevent the graduation documents forgery [4]-[7]. Blockchain also can be combined with IoT (Internet of Things) to support the educational systems and create more interactive communication among students, teachers, employers, and other stakeholders [8]. Despite blockchain's ability and ensuring data integrity, there is still lack of research showing how this blockchain can prevent the fake diploma and academic transcript. This study simulates the process of academic transcript record using blockchain technology (multichain). This research used a qualitative method and conducted lab as a media to show the blockchain implementation on transcript data records.

This research is continuing from the previous study [9]. The previous study discussed about the process and value chain in academic transcript. The process was confirmed by all users in 
Focus Group Discussion. This research will show the simulation of data recording of academic transcript in Blockchain (Multichain) after all process is done.

The structure of this paper divided into several sections. The first section is introduction, which describes the background of the study and the issue or problem discussed and solved in this research. The second section is Literature Review which discuss about the theoretical background to support this research. The third section is Methodology which explain the research design and technique used in this research. The fourth section is Result and Discussion, which describes the prototype and result of Focus Group Discussion. The last section is conclusion as the overall information, contribution, and further research.

\section{Literature Review}

\subsection{Blockchain in Higher Education}

Blockchain is the concept of a decentralized network and was first found in 2008 by a group or person named Satoshi Nakamoto [3]. It was first used for cryptocurrency and bitcoin was the first cryptocurrency and gained popularity for years by using blockchain technology. Since then, blockchain is popular and widely used. Blockchain using peer - to - peer ledger for all transaction registration. Blockchain is still categorized as a new technology but the popularity makes many other fields want to adopt blockchain, this mainly because of its capabilities such as immutable, unchangeable, data integrity and transparency. There are several studies discussed about blockchain technology and education, many application proposed such as application to issue diploma certificate, student academic transcript, and other students track record [4].

Blockchain in education field can be found critically important because of the asset is student. They need to be recognized for every track record they made during their study. Not only for the internal university, this data also used by government and company [9].

Some current applications of blockchain in education such as: Open Blockchain for Digital certificate application [10] which provide controls to student certificate for storing and keep the credential. Also support service application and Earning Application which connect between learning and earning [11].

\subsection{Multichain}

Multichain is a blockchain platform first introduced in [12]. Multichain is categorized as private blockchain. Multichain could solve privacy problems, and the management of user permissions by ensuring all activity and transaction inside the blockchain is only visible to the chosen users who have permission. In multichain, user will randomly generate their private key which has a mathematical public address.

Multichain can also be implemented for many blockchain technology based and successfully implemented agricultural food for food tracking, food tracing, and the lifecycle of the food production [13].

\subsection{User Centered Design Method}

User-Centered Design is a methodology that aims to gaining deep understanding about the user needs [14]. User Centered Design (UCD) can be done by using questionnaires, focus group discussions, interviews, paper prototyping, and so on as long as users contribute in the process [15]. UCD will engage user closely with the project in designing the solution and put the user as the center of design. This research using User Centered Design Method and several Focus Group Discussion is done for this research.

UCD contains of four phases, they are [16]:

- $\quad$ Phase 1 is Specify Context of Use, in this phase, observation and literature review was carried out to gather the requirements.

- Phase 2 is Specify Requirement, in this phase, after all information is gathered, Focus Group Discussion (FGD) with users is conducted to specify the requirements and make categorization based on the result in the first phase

- Phase 3 is Produce Design Solution. After knowing about the requirements, the design prototype is created in this phase and Focus Group Discussion is also conducted to show the prototype to users and gather the feedback.

- Phase 4 is Evaluate Design, this phase is the evaluation phase after the prototype is created. This evaluation will involve the user as the center of this methodology.

\subsection{Simulation}

Simulation is a process for conducting trials close to the actual situation and is often used because they are fast and cheap [17]. Simulation is used to ensure the information can be recorded in blockchain (Multichain).

Focus group discussion was conducted by inviting 7 universities. FGD aims to show the prototype flow simulation to the users/participants and get the feedback for future development.

The overall process of the simulation is shown in figure 2 below:

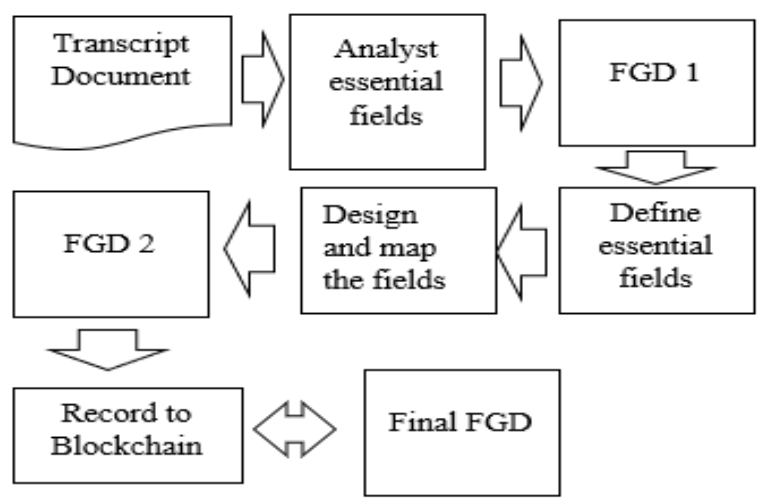

Figure 1. Simulation Phase 
- Transcript Document used for this simulation is the original transcript provided from one university, it is used to resemble the real condition

- Analyst essential fields \& FGD 1, the important fields were discussed in the document transcript and FGD confirmed the results with other people who have the same interest.

- Define essential fields, at this stage a decision has been made on which fields are important in this simulation

- Design and Map the fields. At this stage the fields that have been agreed are mapped into the blockchain (Multichain)

- Record to Blockchain, at this stage all information is entry directly into the Blockchain

- Final FGD, in this process the final data or information validation is carried out in the system to ensure that the data or information stored is following user needs and has been agreed upon.

\section{Methodology}

This research also using User Centered Design (UCD) concept and method by exploring the user needs and requirements [14]. Using this concept, users will understand the technology and the prototype built more easily, and we will easily get what the users need the most. We conducted several Focus Group Discussion (FGD) to know more about the user needs, by inviting 7 universities and to validate and confirm the process in their universities.

The research design and simulation steps using User Centered Design (UCD) are explained in this figure for more details:

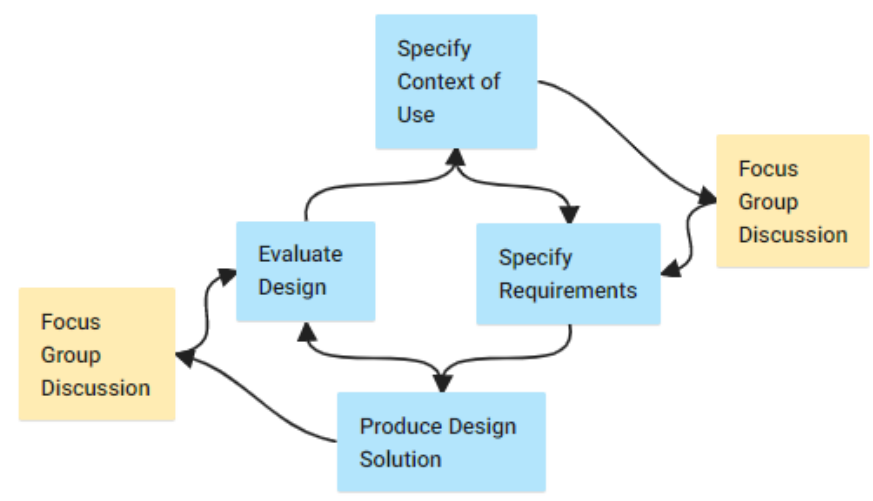

Figure 2: Research Design \& Simulation Steps

\section{Result and Discussion}

This research is the continue study from the previous research. The previous research discussed about the value chain and activity process in producing academic transcript [9]. This research will not discuss about the process and raw data before the data recording (smart contract process), meanwhile, the discussion is about the simulation of data record in Blockchain (Multichain).

The diploma certificate also recorded in this multichain of blockchain from previous research [3]. Diploma certificate is defined as the asset in Blockchain (Multichain) and this research will discuss another asset of graduation document, which is academic transcript.

To highlight the business process of how academic transcript is created will be described on figure 3 [9]:

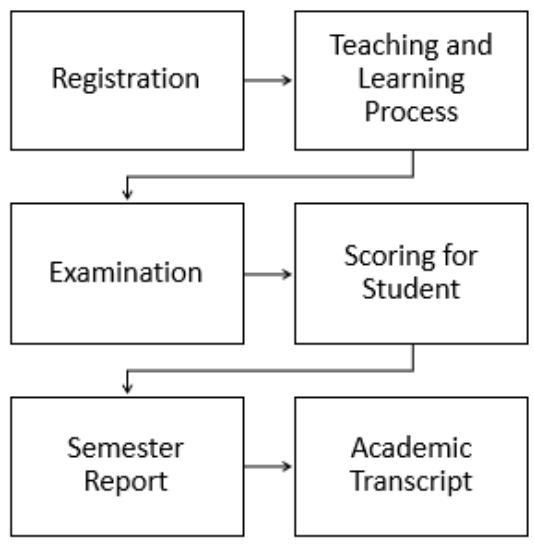

Figure 3: Process of Academic Transcript

To highlight the application process, can be seen on figure 4 :

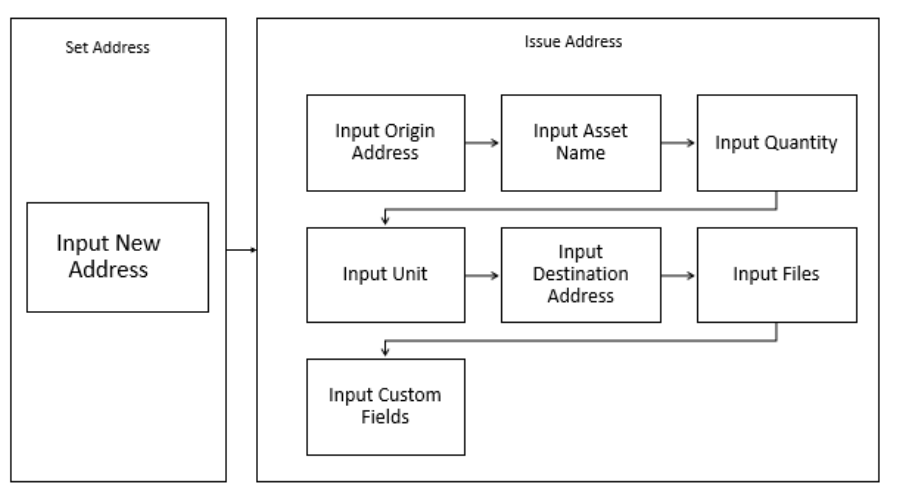

Figure 4. System Process

The more detail explanation of each component will be described below.

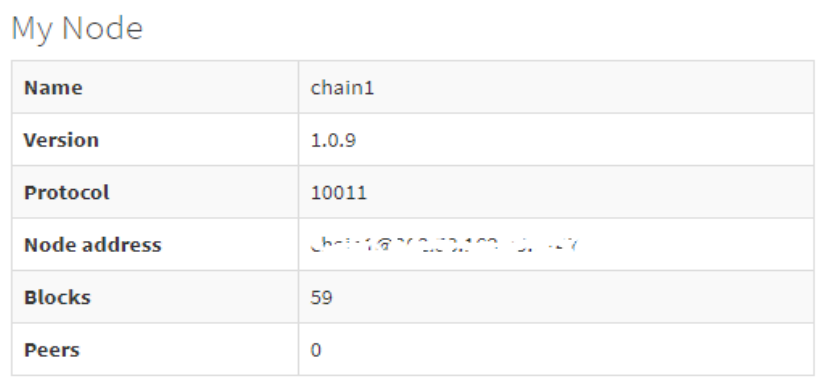

Connected Nodes

Figure 5: Node

\subsection{Node and Address}

Just review about the Node and Address in the Blockchain (Multichain), the node is one private blockchain and many 
addresses can be created in this node. Every address can have several assets, example: diploma certificate, academic transcript, achievement certificate, etc.

The configuration for this simulation using Node name "chain1", version 1.0.9, protocol 10011, node address represents the entity (university, student). The more detail is shown on figure 5. As presented in Figure 5, it is the node used in the blockchain.

Exhibit at Figure 6, presenting the example of address in blockchain node, this address could be represented the university or students.

\begin{tabular}{|l|l|}
\hline Label & Student A- change label \\
\hline Address & 12ZUrxk49tfMp1sNQQgZdoQ2ztDdbc3Jzo Jj1j \\
\hline Permissions & $\begin{array}{l}\text { connect, send, receive, issue, create, mine, admin, } \\
\text { activate - change }\end{array}$ \\
\hline
\end{tabular}

Figure 6: Address in Blockchain

Once the address is recorded on the blockchain, the user can create asset for each address. The Asset for example diploma certificate, academic transcript, etc.

Exhibit at Figure 7 and 8, show the process of data entry for academic transcript.

In this simulation (using as-is Multichain), to process the data record into Blockchain (Multichain), the academic transcript data is divided into two assets. The first asset describes the student general information, and the second asset describe about the detail grade and course information. The figure 4 and 5 show the input process.

This simulation is done manually for easy process understanding. The first step, user need to ensure the first entity (From Address) is the university, then create the asset name (ex: TranscriptSeri1). User also need to determine the quantity and unit of the Asset. Then choose the address (to Address which represent student). The field can be seen on Figure 7. The first transcript named TranskripSeril

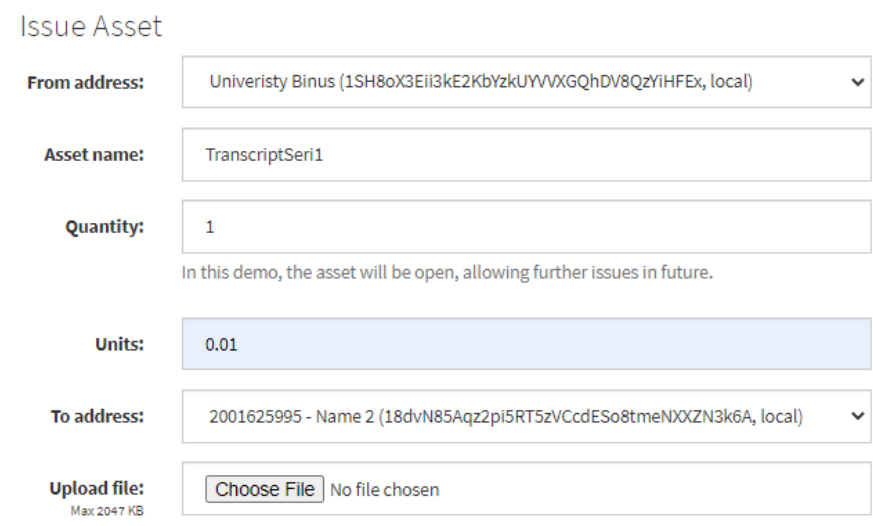

Figure 7 (a): Issue Asset TranscriptSeri1 Part 1

User then need to fill out the fields as the important parameter on the academic transcript. For more detail information of the fields to be entry. It exhibits in figure $7 \mathrm{~b}$. The data is presented in Indonesian Language as real data.

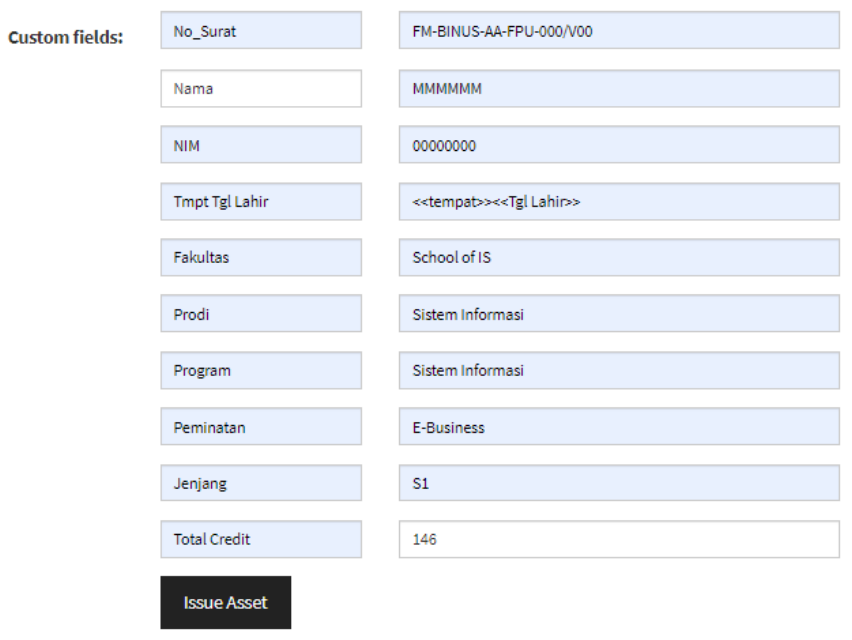

Figure 7 (b): Issue Asset TranscriptSeril Part 2

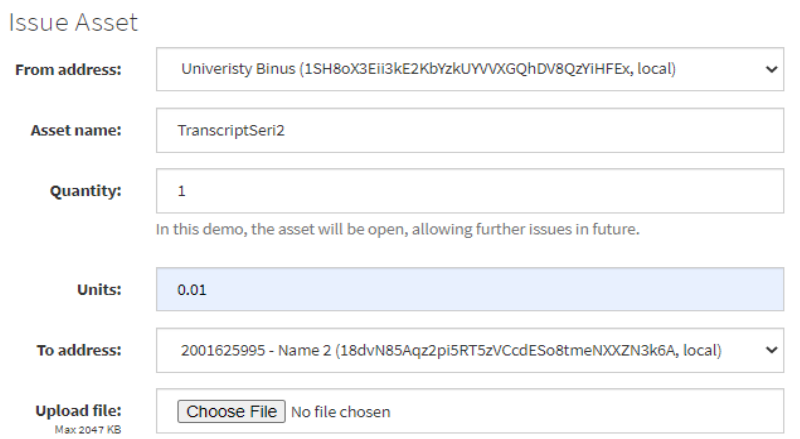

Figure 8 (a): Issue Asset TranscriptSeri2 Part 1

Custom fields:

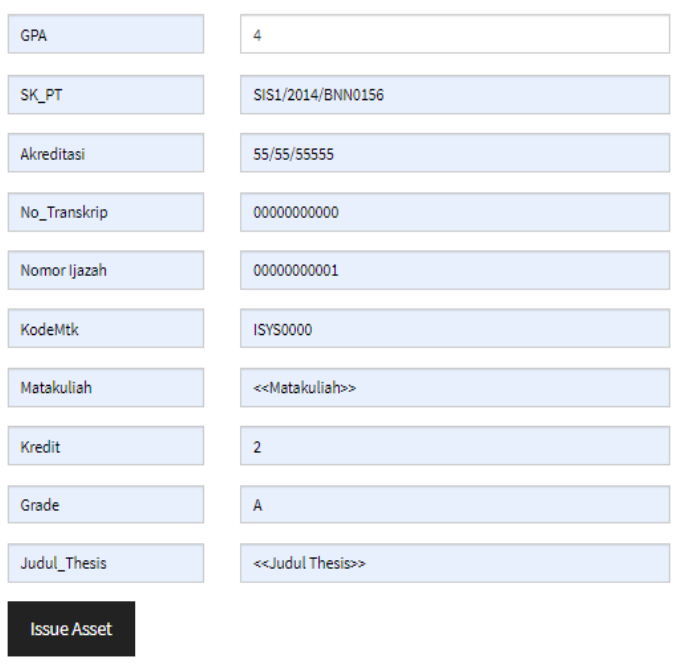

Figure 8b: Issue Asset TranscriptSeri2 Part 2

Based on FGD Result, some fields are important in Academic Transcript. The fields are then filled to the blockchain as exhibit in figure $5 \mathrm{~b}$, all fields on figure $7 \mathrm{~b}$ presented in Indonesian Language as the real simulation:

- Paper No (No_Surat)

- Name (Nama) 
- $\quad$ Student ID (NIM)

- $\quad$ Date of Birth (Tempat Tgl Lahir)

- Faculty (Fakultas)

- Study Program (Prodi)

- Program (Program)

- $\quad$ Streaming (Peminatan)

- Degree (Jenjang)

- Total Credit (Total Credit)

\begin{tabular}{|l|l|}
\hline Name & Transkripseri1 \\
\hline Quantity & 1 \\
\hline Units & 0.01 \\
\hline Issuer & $\begin{array}{l}\text { Univeristy Binus } \\
\text { (1SH80X3Eii3kE2KbYzkUYVVXGQhDV8QZYi } \\
\text { HFEx, local) }\end{array}$ \\
\hline No_Surat & FM-BINUS-AA-FPU-000/NO0 \\
\hline Nama & MMMMMM \\
\hline NIM & 00000000 \\
\hline Tmpt Tgl & $<<$ tempat>><<TgI Lahir >> \\
Lahir & School of IS \\
\hline Fakultas & Sistem Informasi \\
\hline Prodi & Sistem Informasi \\
\hline Program & E-Business \\
\hline Peminatan & S1 \\
\hline Jenjang & 146 \\
\hline Total Credit & \\
\hline
\end{tabular}

Figure 9: Asset Created

Next, on Figure 8a and 8b show the other part of Academic Transcript named as TranscriptSeri2 which have the same flow with figure $7 \mathrm{a}$ and $7 \mathrm{~b}$. The data is presented in Indonesian Language as real data.

The explanation of the detailed fields:
- $\quad$ University No (SK_PT)

- Accreditation (Akreditasi)

- Transcript Number (No_Transkrip)

- Diploma Certificate No (Nomor Ijazah)

- Course Code (Kode Mtk)

- Course Name (Matakuliah)

- $\quad$ Credit (Kredit)

- Grade

- Thesis Title (Judul Thesis)

After the Academic Transcript is created and issued, this academic transcript is recorded and cannot be update. Figure 9 and 10 show the successful of data entry.

\begin{tabular}{|l|l|}
\hline Name & Transkripseri2 \\
\hline Quantity & 1 \\
\hline Units & 0.01 \\
\hline Issuer & $\begin{array}{l}\text { Univeristy Binus } \\
\text { (1SH80X3Eii3kE2KbYzkUYVVXGQhDV8QzYi } \\
\text { HFEx, local) }\end{array}$ \\
\hline GPA & 4 \\
\hline SK_PT & $55 / 55 / 55555$ \\
\hline Akreditasi & $55 / 55 / 55555$ \\
\hline No_Transkrip & 00000000000 \\
\hline Nomor ljazah & 00000000001 \\
\hline KodeMtk & ISYSO000 \\
\hline Matakuliah & $<<$ Matakuliah $>>$ \\
\hline Kredit & 2 \\
\hline Grade & A \\
\hline Judul_Thesis & $<<$ Judul Thesis $>>$ \\
\hline
\end{tabular}

Figure 10: Another Asset Created

Figure 10 is the real example of Academic Transcript published from university to students that was successfully recorded to Blockchain (Multichain).

- GPA

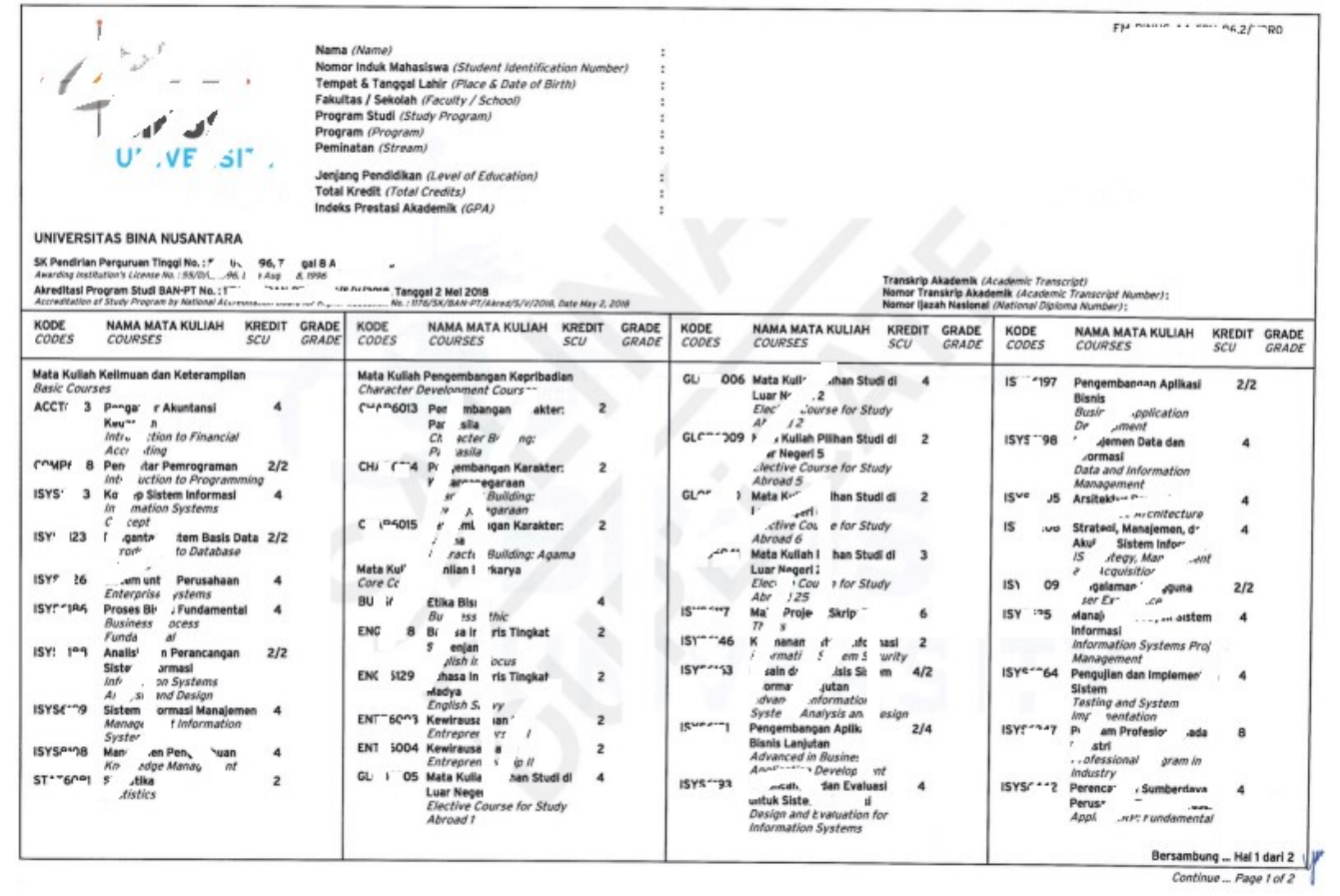

Figure 11: Example of Real (Current) Printed Academic Transcript The data on the picture was blurred for confidential purpose 
The simulation and the result are presented to the FGD participant on November $5^{\text {th }}$ and $12^{\text {th }} 2020$. Several feedbacks from FGD regarding to the issue of security, training for university users, and the data synchronization with government. The participants of FGD are from Binus University, Indonesia Open University, Darma Persada University, Pelita Harapan University, Kalbis University, STP Trisakti, and Universitas Negeri Jakarta with all total of 17 participants.

\section{Conclusion}

Blockchain in education is quite popular recently. Blockchain in education can be used to validate the data records and asset for students such as diploma certificate and academic transcript. This paper simulates the application prototype for recording Academic Transcript Data to prevent the forgery as many cases happen because of fake diploma dan academic transcript. Using blockchain technology will ensure the data integrity. The Focus Group Discussion gives positive results. All participants agree and approved the application. The users also think it is appliable to their university, but another improvement needs to be made regarding data standardization and infrastructure. Based on the simulation, Blockchain (Multichain) is possible to be implemented in University for Academic Transcript record.

The limitation of this research is because this is still in very initial stage of development, this prototype simulation is using Multichain with no modification and only implemented with one node so there is no backup if any error or crash happened. Next project will improve this research.

\section{Conflict of Interest}

The authors declare no conflict of interest.

\section{Acknowledge}

This study is supported by the Directorate General of Strengthening for Research and Development, Ministry of Research, Technology, and Higher Education, Republic of Indonesia as a part of Penelitian Terapan Unggulan Perguruan Tinggi Research Grant to Bina Nusantara University entitled "Implementasi Blockchain Platform untuk Menciptakan "Good Governance" pada Perguruan Tinggi" or "The Implementation of Blockchain Platform to Create "Good Governance" in Higher Education" with contract number: 12/AKM/PNT/2019 and contract date: 27 March 2019.

\section{References}

[1] Amirullah, Dipenjara karena Kasus Ijazah Palsu, Ini Perjalanan Karir Nurul Qomar, Dari Pelawak hingga Politisi (Arrested due to Fake Diploma Certificate, this is the career journey of Nurul Qomar, from Comedian to Politician), 2020.

[2] Y. Linggasari, Menteri Nasir: 187 Pemilik Ijazah Palsu Punya Jabatan Penting (187 Fake Diploma Certificate Owner has important Position), 2015.

[3] Meyliana, Y.U. Chandra, C. Cassandra, H.A.E. Widjaja, . Surjandy, E. Fernando, J.A. Sunandar, H. Prabowo, "Blockchain Technology for University Diploma Certificate," (Conrist 2019), 193-198, 2020, doi:10.5220/0009907801930198.

[4] A. Alammary, S. Alhazmi, M. Almasri, S. Gillani, "Applsci-09-02400.Pdf," 2019.

[5] Meyliana; Cadelina Cassandra; Surjandy; Henry Antonius Eka Widjaja; Harjanto Prabowo; Erick Fernando; Yakob Utama Chandra, "A Blockchain Technology-Based for University Teaching and Learning Processes," 2020
International Conference on Information Management and Technology (ICIMTech), 4, 2020, doi:10.1109/ICIMTech50083.2020.9211209.

[6] D. Tapscott, A. Tapscott, "THE BLOCKCHAIN REVOLUTION \& Higher Education.," Education Review, 52(2), 10-24, 2017.

[7] M.B. Hoy, "An Introduction to the Blockchain and Its Implications for Libraries and Medicine," Medical Reference Services Quarterly, 36(3), 273279, 2017, doi:10.1080/02763869.2017.1332261.

[8] T. Alam, M. Benaida, "Blockchain and internet of things in higher education," Universal Journal of Educational Research, 8(5), 2164-2174, 2020, doi:10.13189/ujer.2020.080556.

[9] Meyliana, Y.U. Chandra, C. Cassandra, . Surjandy, E. Fernando, H.A.E. Widjaja, H. Prabowo, "A Proposed Model of Secure Academic Transcript Records with Blockchain Technology in Higher Education," in ConRist 2019, 172-177, 2020, doi:10.5220/0009907401720177.

[10] G. Chen, B. Xu, M. Lu, N.-S. Chen, "Exploring blockchain technology and its potential applications for education," Smart Learning Environments, 5(1), 1-10, 2018, doi:10.1186/s40561-017-0050-x.

[11] B. Awaji, E. Solaiman, A. Albshri, "Blockchain-based applications in higher education: A systematic mapping study," ArXiv, (June), 2020.

[12] G. Greenspan, "MultiChain Private Blockchain - White Paper," 1-17, 2013.

[13] A. Ismailisufi, T. Popović, N. Gligorić, S. Radonjić, S. Šandi, "A Private Blockchain Implementation Using Multichain Open Source Platform," (February), 2020, doi:10.1109/IT48810.2020.9070689.

[14] Interaction Design Foundation, User Centered Design, 2020.

[15] J. Sujan, S. Roy, D. Fels, "User Centered Design Methods and Their Application in Older Adult Community USER CENTERED DESIGN METHODS AND THEIR Introduction :," (July), 2016, doi:10.1007/978-3319-40349-6

[16] Z. Almeraj, "A User Centered Design Roadmap for Researchers and Designers Working with Visually Impaired and Blind Children A User Centered Design Roadmap for Researchers and Designers Working with Visually Impaired and Blind Children," (February), 2019.

[17] H. Leslie, H. Spits, E. Abdurachman, "A Proposed Supply Chain Model of Blockchain Technology-Based in Automotive Component Industry," (January), 2020, doi:10.35940/ijrte.E6440.018520. 